\title{
An Exploratory Study of the Relationship between Supply Chain Management Practices and Technical Efficiency of Jordanian Manufacturing Companies
}

\author{
Loay Salhieh (Assistant Professor) \\ College of Business, German Jordanian University \\ P.O. Box 35247, Amman 11180, Jordan \\ Tel. 962-6-530-066 E-mail: Loay.Salhieh@gju.edu.jo
}

Received: April 5, 2011

Accepted: August 4, 2011 Published: December 1, 2011

doi:10.5539/ijbm.v6n12p126

URL: http://dx.doi.org/10.5539/ijbm.v6n12p126

\begin{abstract}
Recent arguments states that competition is no longer between organizations, but among supply chains to support different competitive priorities. Effective supply chain management (SCM) practices have become a recognized way of achieving competitive advantage and improving organizational financial performance. This paper presents an exploratory study of the relationship between (SCM) practices and organizational financial performance. Although research on the relationship was investigated by relating SCM practices and single organizational financial performance, but no research have surrogated many organizational financial performance in one measurement. Technical efficiency was used to surrogate organizational financial performance of Jordanian manufacturing companies. Data for the study was collected from 28 manufacturing companies registered in first market of Amman Stock Exchange. The results indicate a strong relationship between SCM practices and bottom-line profits of an organization.
\end{abstract}

Keywords: Supply chain management, Technical efficiency, DEA, Jordan

\section{Introduction}

Over the last decade the competitive landscape has shifted from lowest priced product, highest-quality or best-performing product to the ability to respond quickly to market needs and get the right product to the right customer at the right time (Suhong et al., 2005). This shift toward speed has pushed organizations to compete with their entire supply chain (Hult et al., 2007). Consequently understanding and practicing supply chain management (SCM) has become a mandate to compete and improve supply chain surplus in the global arena (Moberg et al., 2002).

The early attempts of empirical research in SCM have been limited at developing instruments capable of measuring SCM practices (Donlon, 1996; Tan et al., 1998; Alvarado and Kotzab, 2001; Chen and Paulraj, 2004; Suhong et al., 2005). Most recently, scholars like Suhong et al. (2006) have focused their research efforts into exploring the relationship between practices of SCM and organizational performance. They have used financial and market criteria to operationalize organizational performance (return on investment, market share, profit margin on sales, the growth of return on investment, the growth of sales and the growth of market share. Also, Lenny et al. (2007) investigated the relationship among SCM practices, operational performance and SCM-related organizational performance.

These studies and others have produced various results due to operationalizing the performance of the organization subjectively and objectively. Supply-chain driven organizational performance falls into three categories (Khan et al., 2009). First, resource performance reflects value addition in the form of achieving efficiency. Second, output performance reflects value addition as the firm's ability to provide high levels of customer service. Last, flexibility performance reflects value addition as the firm's ability to respond. This study will capture the performance of the organization through measuring technical efficiency by the use of data envelopment analysis (DEA) technique.

The primary goal of this paper is to explore the relationship among SCM practices and technical efficiency in manufacturing companies. In other words, this paper studies the extent to which SCM practices contribute to the efficiency of an organization. Since there are many measures of efficiency (Saha and Ravisanker, 2000), this 
paper mainly deals with technical efficiency of manufacturing companies in Jordan.

The remainder of this paper is organized as follows. The literature review regarding SCM practices, its impact on organizational performance, and technical efficiency is discussed in the next section. Section three offers research framework. Section four discusses research methodology. Data and results are offered in section five. The final section draws implications and conclusions.

\section{Literature Review}

SCM is a set of practices utilized to efficiently and effectively integrate all different stages in the supply chain in order to produce and deliver goods at the right quantities, to the right locations, and at the required time with minimum costs while meeting customer needs (Simchi et al., 2003). SCM practices have been documented in measurement studies as well in research explored the relationship of SCM practices and organizational performance. Recent studies have begun to propose SCM practices as a multi-dimensional concept that covers upstream, internal and downstream side of a supply chain (Suhong et al., 2005). Their research has six empirically validated dimensions which include strategic supplier partnership, customer relationship, information sharing, information quality, internal lean practices and postponement. Also, Chen and Paulraj (2004) have developed a conceptual framework and an instrument that would help researchers better understand the scope of both the problems and the opportunities associated with SCM from a holistic view. Their research has fifteen empirically validated dimensions and some of them do address SCM practices. This paper will adopt dimensions related to SCM practices from both mentioned papers as will be discussed in the research framework section.

Since 1980s, SCM has been considered as one of the most driving forces for firms to improve their competitive advantage and performance (Kannan and Tan, 2005; Chin et al., 2010). Some studies have examined specific practices of SCM to analyze the impact on organizational performance, while others operationalize SCM practices as a multidimensional construct and investigated the impact on organizational performance (Suhong et al., 2006; Kim, 2006; Chin et al., 2010).

Organizational performance has been defined as how well an organization achieves its market-oriented goals as well as its financial goals (Yamin et al., 1999). Most studies operationalize organizational performance using both financial and market criteria (Suhong et al., 2006) to compare the performance among organizations. These criteria lack the characteristics of being able to address the whole in order to benchmark organizations (Wong and Wong, 2005). This paper suggests the use of technical efficiency to benchmark the performance of an organization using DEA modeling as discussed in the next paragraph.

Techniques used in measuring firm's efficiency can be grouped into three categories: ratio analysis, parametric methods and nonparametric methods. These techniques have both advantages and disadvantages (DÜzakin and DÜzakin, 2006). The major disadvantage of ratio analysis is inappropriateness of making decisions based on one single ratio when there are multiples of inputs and outputs. DEA is a nonparametric method in which multiple inputs and outputs are used to measure firm's performance. DEA enables the measurement of relative efficiency. For the sake of brevity of this paper, detailed discussions of this method are not described here. Important references are provided to help the interested readers. So, DEA was used by many scholars to measure the efficiency of a manufacturing firm (Chandra et al., 1998; Friedman and Stern, 1998; Shammari, 1999; Sena, 2001; DÜzakin and DÜzakin, 2006; Chen and Chen, 2009; and Halim, 2010).

In order to apply DEA, it is important that inputs and outputs considered for the study be specified and justified. Various studies on the measurement of efficiency in manufacturing firms with the utilization of DEA have used several inputs and outputs. Chandra et al. (1998) have specified their inputs as number of employees, average annual investment over last ten years, and their outputs were annual sales values. On the other hand, Friedman and Stern (1998) specified their inputs as assets, average wage man-hours worked by employees, labor cost, materials and expenses, but their outputs were revenue, export revenue, and income due to work and repairs and assts. Furthermore, Shammari (1999) considered number of employees, paid in capital and fixed assets as inputs, but market value, net sales and net income after taxes as outputs. Also, Zhu (2000) inputs were number of employees, assets and stakeholders equity, but the outputs were revenues and profits. In the same line, Chen and Chen (2009) considered their inputs as total assets, operation cost, and operation expenses and specified one variable output as net sales. This study will discuss its inputs and outputs with justification in the research framework section in line with previous studies.

\section{Research Framework}

Fig. 1 presents the proposed SCM practices framework. The framework explores the existence of a relationship between SCM practices and firm's technical efficiency.

\section{Insert Figure 1 - Here}


SCM practices are conceptualized as a five-dimensional construct. These dimensions are adopted from previous empirically validated studies (Chen and Paulraj, 2004; Sunhong et al., 2006). The five dimensions are strategic supplier partnership, customer relationship, information technology, logistic integration, delivery practices. Each dimension with representative items is provided in appendix A. For a detail description of the adopted dimensions, the interested reader can review studies conducted by Chen and Paulraj (2004), Suhong et al. (2005, 2006), and Zhou, (2007).

A considerable amount has been written documenting that organizational performance can be operationalize through measuring its efficiency using DEA method (Sena, 2001; DÜzakin and DÜzakin, 2006; Chen and Chen, 2009; and Halim, 2010). Previous studies measuring efficiency in manufacturing firms by the use of DEA method have identified several inputs and outputs (Chandra et al., 1998; Friedman and Stern, 1998; Shammari, 1999; Zhu, 2000; and Chen and Chen, 2009). In line with previous literature, this study will specify its inputs and outputs with justification in order to measure technical efficiency using DEA method.

The primary objectives of SCM in the short-term and long-term are to increase productivity, reduce inventory, increase market share and profits. SCM practices do influence the financial aspects of an organization (Krajewski et al., 2010) such as:

Total revenue: Percent of on-time deliveries to customers will increase total revenue because satisfied customers will buy more services and products from the firm.

Net income: Being able to buy materials or services at a better price and transform them more efficiently into services or products will improve a firm's cost of goods sold and ultimately its net income. Also, contribution margin will improve resulting in greater profit.

Operating expenses: Operating an organization with minimal expenses will increase profits.

Cash flow: Positive net cash flows can be achieved by reducing lead times and backlogs of orders.

Working capital: Decreasing weeks of supply or increasing inventory turns reduces the working capital needed to finance inventories. Reduction in working capital can be accomplished by improving the customer relationship, order fulfillment, or supplier relationship processes.

Return on assets: Reducing aggregate inventory investment and fixed investments, or increasing net income by better cost management will increase return on assets.

Based on the above justification and the interest of operational activities in an organization, this study will consider total current assets, working capital, and operating expenses as its inputs, while operating revenue, net income and cash flow from operating activities as its outputs.

\section{Research Methodology}

This study is based on an exploratory data analysis regarding SCM practices of Jordanian manufacturing companies. These manufacturing companies were selected for the analysis due to availability of financial data. This study administered a survey and collected quantitative data to explore the existence of a relationship between SCM practices and organizational performance.

A survey instrument was adopted from Chen and Paulraj (2004), Suhong et al. (2005, 2006), and Zhou, (2007). Five constructs of SCM practices were proposed which were felt important for SCM practices as shown in Appendix A. A sample of 28 manufacturing companies registered in the first market of Amman Stock Exchange was selected. A total of 140 questionnaires were personally administered to those companies. The number of returned questionnaire that were found to be usable in this study was 126 , which represented about $90 \%$ response rates. Cronbach's alpha-values in this study were all greater than 0.71 (with a maximum value of 0.92 ). The statistical results confirm the significantly high consistency of the questionnaire.

The quantitative aspect of this study was collected in order to measure the technical efficiency of these manufacturing companies. This study will use DEA method to measure the technical efficiency of companies registered in the first market of Amman Stock exchange in the year 2007-2009. The data used to measure the technical efficiency is the financial information available at the Stock Exchange. As justified in the research framework section, the inputs considered are total current assets, working capital, and operating expenses, while operating revenue, net income and cash flow from operating activities are considered as outputs.

\section{Data and Results}

Using the non-parametric Kruskal-Wallis test on the instrument item (SCM practice) found no significant differences between the manufacturing companies in different industries as shown in the p-value in table (1). Thus, it is appropriate to treat the companies as a homogeneous sample for further analysis. 
Descriptive statistics for the research dimensions are shown in table (2). The results show that the investigated companies are moderate in their adoptions of supply chain practices.

\section{Insert Table 2- Here}

In this study, performances of the organizations were analyzed by input oriented model under constant returns to scale (CRS) assumption. Objectives of input oriented model are to minimize inputs while producing at levels than given output levels (Cooper et al., 2000). This study believes recommendations about reducing input values are more appropriate than the output oriented model because SCM practices should reduce inventory and costs associated with transportation, warehousing, transaction costs and lead times. Also, constant returns to scale (CRS) assumption is appropriate than variable returns to scale (VRS) assumption (DÜzakin and DÜzakin, 2006). This study analyzed the correlation between inputs and the outputs variables from 2007 to 2009. The results in Table 3 showed that the Pearson correlation between the inputs and outputs variables are positive and the requirements of isotonicity condition is satisfied for the DEA analysis (Chen and Chen, 2009).

\section{Insert Table 3 - Here}

This study used DEA to evaluate the operational performance of the sample companies. As shown in Table 4, the average of CRS efficiency of the sample from 2007 to 2009 is 75.07 percent. Overall the performance of the sample was slightly better in 2009 as indicated by the average.

\section{Insert Table 4 - Here}

A simple correlation test was conducted among the overall construct (SCM practice) and technical efficiency. The correlation was 0.864 at a p-value of 0.003 . Accordingly, the overall construct (SCM practice) was examined in relation to its impact on technical efficiency. A simple regression was conducted with the total score of SCM practices as the independent variable and technical efficiency as the dependent variable. The p-value for the regression test is shown in figure (2). Apparently, the overall SCM practices do have an effect on technical efficiency. Also, the five SCM practices were examined in relation to their impact on technical efficiency. A multiple regression test was conducted, with each practice as the independent variable, and technical efficiency as the dependent variable. The p-values for each practice are shown in figure (3). Apparently all practices have a significant effect on technical efficiency at $\alpha=0.05$ except strategic customer relationship (SCR). Consequently that could be explained as the reliance of customer on those manufacturing companies as their sole providers of finished goods and these customers do not have a marginal effect on the operations of the manufacturing companies.

Insert Figure 2 - Here

Insert Figure 3 - Here

\section{Conclusions}

Current research of SCM practices are targeted toward finding the impact on individual measures of organizational financial performance. The individual constructs of SCM practices might have different impacts on these performances. This study suggested that organizational financial performance should be surrogated in one measurement that captures the complexity of operational activities of an organization. Technical efficiency was suggested as a means to capture the impact of SCM practices on different organizational financial performance. The main objective of this paper was to explore the impact of SCM practices on organizational performance in monetary value. The paper results show the significant correlation between SCM practices and technical efficiency as a measurement of organizational financial performance. The measures of SCM practices provided in this study can be useful to managers in benchmarking their current SCM practices and their impact on organizational financial performance against their competitors. This study offered insight about the role of SCM practices and its contribution to bottom-line profits.

\section{References}

Alvarado, U.Y., \& Kotzab, H. (2001). Supply Chain Management: the Integration of Logistics in Marketing. Industrial Marketing Management, Vol. 30, No. 2, pp. 183-198. http://dx.doi.org/10.1016/S0019-8501(00)00142-5

Chandra, P., Cooper, W., Shangling, L., \& Rahman, A. (1998). Using DEA to evaluate 29 Canadian textile companies considering returns to scale. International Journal of Production Economics, Vol. 54, pp. 129-141. http://dx.doi.org/10.1016/S0925-5273(97)00135-7

Chen, I.J., and Paulraj, A. (2004). Towards a Theory of Supply Chain Management: the Constructs and Measurements. Journal of Operations Management, Vol. 22, No. 2, pp. 119-150. http://dx.doi.org/10.1016/j.jom.2003.12.007 
Chen, Y., and Chen, B. (2009). Using data envelopment analysis (DEA) to evaluate the operational performance of the wafer fabrication industry in Taiwan. Journal of Manufacturing Technology Management, Vol. 20 No. 4, pp. 475-488. http://dx.doi.org/10.1108/17410380910953739

Chin, O., Liu, F., Hung, Y., and Yen, D. (2010). A structural model of supply chain management on firm performance. International Journal of Operations \& Production Management, Vol. 30 No. 5, pp. 526-545. http://dx.doi.org/10.1108/01443571011039614

Cooper, W.W., Seiford, L.M., \& Tone, K. (2000). Data Envelopment Analysis-A Comprehensive Text with Models, Applications, References and DEA-Solver Software. Kluwer Academic Publishers.

Donlon, J.P. (1996). Maximizing Value in the Supply Chain. Chief Executive, Vol. 117, October, pp. 54-63.

DÜzakin, E., and DÜzakin, H. (2006). Measuring the performance of manufacturing firms with super slacks based model of data envelopment analysis: An application of 500 major industrial enterprises in Turkey. European Journal of Operational Research.

Friedman, L., \& Stern, Z.S. (1998). Combining ranking scales and selecting variables in the DEA context: The case of industrial branches. Computers Operations Research, Vol. 25 No. 9, pp.781-791. http://dx.doi.org/10.1016/S0305-0548(97)00102-0

Halim, R. (2010). Marketing productivity and profitability of Indonesian public listed manufacturing firms: An application of data envelopment analysis (DEA). Benchmarking: An International Journal, Vol. 17 No. 6, pp. 842-857.

Hult, G.T.M., Ketchen, D.J., and Arrfelt, M. (2007). Strategic Supply Chain Management: Improving Performance through a Culture of competitiveness and knowledge development. Strategic Management Journal, Vol. 28 No. 10, pp. 1035-52. http://dx.doi.org/10.1002/smj.627

Kannan, V.R., and Tan, K.C. (2005). Just in time, total quality management, and supply chain management: understanding their linkages and impact on business performance. Omega, Vol. 33, pp. 153-62. http://dx.doi.org/10.1016/j.omega.2004.03.012

Khan, A., Bakkappa, B., and Sahay B. (2009). Impact of Agile Supply Chains' Delivery Practices on Firms' Performance: Cluster Analysis and Validation. Supply Chain Management: An International Journal, Vol. 14, No.1, pp. 41-48. http://dx.doi.org/10.1108/13598540910927296

Kim, S. (2006). Effects of supply chain management practices, integration and competition capability on performance. Supply Chain Management: An International Journal, Vol. 11 No. 3, pp. 241-248. http://dx.doi.org/10.1108/13598540610662149

Krajewski, L., Ritzman, L., and Malhtra, M. (2010). Operations Management: Processes and Supply Chains, $9^{\text {th }}$ edition. Pearson Education, Inc., USA.

Lenny, S.C., Demirbag, M., Bayraktar, E., Tatoglu, E., and Zaim, S. (2007). The impact of supply chain management practices on performance of SMEs. Industrial Management \& Data Systems, Vol. 107, No. 1, pp. 103-124. http://dx.doi.org/10.1108/02635570710719089

Moberg, C.R., Cutler, B.D., Groso, A., \& Speh, T.W. (2002). Identifying Antecedents of Information Exchange within Supply Chain. International Journal of Physical Distribution \& Logistic Management, Vol. 32, No. 9, pp. 755-770. http://dx.doi.org/10.1108/09600030210452431

Saha, A., and Ravisankar, T.S. (2000). Rating of Indian Commercial Banks: A DEA approach. European Journal of Operational Research, Vol. 124, pp. 187-203. http://dx.doi.org/10.1016/S0377-2217(99)00167-8

Sena, V. (2001). The Generalized Malmquist index and capacity utilization change: an application to the Italian manufacturing, 1989-1994. Applied Economics, Vol. 33, pp.1-9. http://dx.doi.org/10.1080/00036840122173

Shammari, M. (1999). Optimization modeling for estimating and enhancing relative efficiency with application to industrial companies. European Journal of Operational Research, Vol. 115, pp. 488-496. http://dx.doi.org/10.1016/S0377-2217(98)00025-3

Simchi-Levi, D., Kaminsky, P., and Simichi-Levi, E. (2003). Designing and Managing the Supply Chain Concepts, Strategies and Case Studies. McGraw-Hill Publishing, New York, NY.

Suhong, Li., Subba Rao, S., Ragu-Nathan, T.S., \& Ragu-Nathan B. (2005). Development and Validation of a Management instrument for Studying Supply Chain Management Practices. Journal of Operations Management, Vol. 23, pp. 618-641. http://dx.doi.org/10.1016/j.jom.2005.01.002

Suhong, Li., Subba Rao, S., Ragu-Nathan, T.S., \& Ragu-Nathan B. (2006). The Impact of Supply Chain Management Practices on Competitive Advantage and Organizational Performance. Omega, Vol. 34, pp. 
107-124. http://dx.doi.org/10.1016/j.omega.2004.08.002

Tan, K.C., Kannan, V.R., \& Handfield, R.B. (1998). Supply Chain Management: Supplier Performance and Firm Performance. International Journal of Purchasing and Materials Management, Vol. 34, No. 3, pp. 2-9.

Wong, W., and Wong K. (2008). A review on benchmarking of supply chain performance measures. Benchmarking: An International Journal, Vol. 15 No. 1, pp. 25-51.

Yamin, S., Gunasekruan, A., and Mavondo, FT. (1999). Relationship between generic strategy, competitive advantage and firm performance: an empirical analysis. Technovation, Vol. 19 No. 8, pp. 507-18. http://dx.doi.org/10.1016/S0166-4972(99)00024-3

Zhou, H., and Benton, W. (2007). Supply chain practice and information sharing. Journal of Operations Management, Vol. 25, pp. 1348-1365. http://dx.doi.org/10.1016/j.jom.2007.01.009

Zhu, J. (2000). Multi-factor performance measure model with an application to Fortune 500 companies. European Journal of Operational Research, Vol. 123, pp.105-124. http://dx.doi.org/10.1016/S0377-2217(99)00096-X

Table 1. Kruskal-Wallis Test (p-value results)

\begin{tabular}{|c|c|}
\hline Industry Type & Kruskal-Wallis test $(\boldsymbol{\alpha}=\mathbf{0 . 0 1})$ \\
\hline Pharmaceutical and Medical Industries & 0.736 \\
\hline Chemical Industries & 0.265 \\
\hline Printing and Packaging & 0.459 \\
\hline Food and Beverages & 0.233 \\
\hline Tobacco and Cigarettes & 0.165 \\
\hline Mining and Extraction Industries & 0.584 \\
\hline Engineering and Construction & 0.354 \\
\hline Electrical Industries & 0.856 \\
\hline Textiles, Leathers and Clothing's & 0.478 \\
\hline
\end{tabular}

Table 2. Descriptive Statistics

\begin{tabular}{|l|c|c|}
\hline Dimensions (SCM practices) & Average & STDEV. \\
\hline Strategic supplier partnership & 3.87 & 0.88 \\
\hline Strategic customer relationship & 3.99 & 0.71 \\
\hline Information technology & 3.23 & 0.86 \\
\hline Logistics integration & 3.66 & 0.74 \\
\hline Delivery practices & 3.80 & 0.79 \\
\hline Total & 3.71 & \\
\hline
\end{tabular}

Table 3. Correlation Coefficients between Variables (p-value)

\begin{tabular}{|l|l|c|c|c|}
\hline & & Operating revenue & Net income & Cash flow \\
\hline \multirow{2}{*}{ Total current assets } & Correlation & 0.881 & 0.792 & 0.819 \\
\cline { 2 - 5 } & p-value & 0.000 & 0.000 & 0.000 \\
\hline \multirow{2}{*}{ Working capital } & Correlation & 0.846 & 0.807 & 0.823 \\
\cline { 2 - 5 } & p-value & 0.000 & 0.000 & 0.000 \\
\hline \multirow{2}{*}{ Operating expenses } & Correlation & 0.990 & 0.912 & 0.929 \\
\cline { 2 - 5 } & p-value & 0.000 & 0.000 & 0.000 \\
\hline
\end{tabular}


Table 4. The CRS Efficiency Scores

\begin{tabular}{|c|c|c|c|c|}
\hline & \multicolumn{3}{|c|}{ Year } & \\
\hline Company & $\mathbf{2 0 0 7} \%$ & $\mathbf{2 0 0 8} \%$ & $\mathbf{2 0 0 9} \%$ & Average \% \\
\hline DMU1 & $80.71 \%$ & $88.92 \%$ & $100.00 \%$ & $89.88 \%$ \\
\hline DMU2 & $84.08 \%$ & $100.00 \%$ & $87.89 \%$ & $90.66 \%$ \\
\hline DMU3 & $77.17 \%$ & $78.80 \%$ & $81.20 \%$ & $79.06 \%$ \\
\hline DMU4 & $44.18 \%$ & $50.22 \%$ & $100.00 \%$ & $64.80 \%$ \\
\hline DMU5 & $66.89 \%$ & $75.56 \%$ & $67.26 \%$ & $69.90 \%$ \\
\hline DMU6 & $62.12 \%$ & $66.57 \%$ & $64.56 \%$ & $64.42 \%$ \\
\hline DMU7 & $63.81 \%$ & $60.49 \%$ & $60.03 \%$ & $61.44 \%$ \\
\hline DMU8 & $71.93 \%$ & $75.16 \%$ & $78.15 \%$ & $75.08 \%$ \\
\hline DMU9 & $74.65 \%$ & $91.15 \%$ & $76.82 \%$ & $80.87 \%$ \\
\hline DMU10 & $81.19 \%$ & $85.00 \%$ & $68.69 \%$ & $78.29 \%$ \\
\hline DMU11 & $69.15 \%$ & $67.47 \%$ & $60.65 \%$ & $65.76 \%$ \\
\hline DMU12 & $72.00 \%$ & $71.20 \%$ & $73.17 \%$ & $72.12 \%$ \\
\hline DMU13 & $63.94 \%$ & $80.25 \%$ & $70.56 \%$ & $71.58 \%$ \\
\hline DMU14 & $67.73 \%$ & $78.08 \%$ & $79.04 \%$ & $74.95 \%$ \\
\hline DMU15 & $73.57 \%$ & $79.84 \%$ & $86.87 \%$ & $80.09 \%$ \\
\hline DMU16 & $73.85 \%$ & $96.92 \%$ & $76.12 \%$ & $82.30 \%$ \\
\hline DMU17 & $61.00 \%$ & $58.47 \%$ & $62.50 \%$ & $60.66 \%$ \\
\hline DMU18 & $60.26 \%$ & $62.60 \%$ & $71.31 \%$ & $64.72 \%$ \\
\hline DMU19 & $87.96 \%$ & $100.00 \%$ & $86.07 \%$ & $91.34 \%$ \\
\hline DMU20 & $100.00 \%$ & $100.00 \%$ & $96.25 \%$ & $98.75 \%$ \\
\hline DMU21 & $100.00 \%$ & $100.00 \%$ & $100.00 \%$ & $100.00 \%$ \\
\hline DMU22 & $88.50 \%$ & $77.53 \%$ & $100.00 \%$ & $88.68 \%$ \\
\hline DMU23 & $59.50 \%$ & $64.18 \%$ & $67.07 \%$ & $63.58 \%$ \\
\hline DMU24 & $54.44 \%$ & $53.18 \%$ & $56.14 \%$ & $54.59 \%$ \\
\hline DMU25 & $64.66 \%$ & $63.87 \%$ & $63.67 \%$ & $64.07 \%$ \\
\hline DMU26 & $47.55 \%$ & $82.12 \%$ & $100.00 \%$ & $76.56 \%$ \\
\hline DMU27 & $67.34 \%$ & $56.65 \%$ & $63.17 \%$ & $62.39 \%$ \\
\hline DMU28 & $73.08 \%$ & $72.29 \%$ & $81.01 \%$ & $75.46 \%$ \\
\hline Average & $71.12 \%$ & $76.30 \%$ & $77.79 \%$ & $75.07 \%$ \\
\hline & & & & \\
\hline
\end{tabular}

\section{SCM Practices}

- strategic supplier partnership

- customer relationship

- information technology

•communication

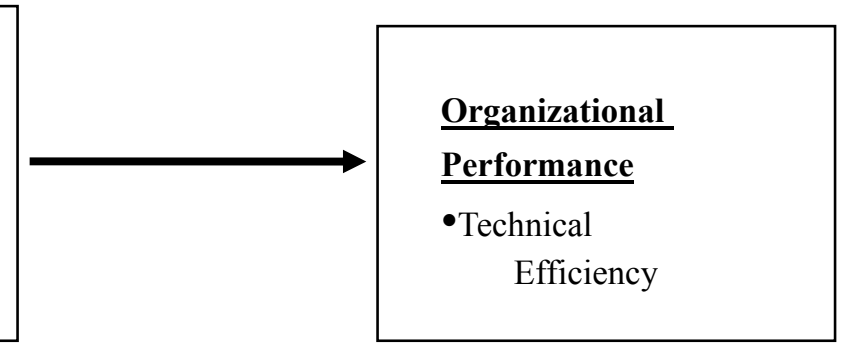

Figure 1. Research Framework 


\begin{tabular}{|c|c|c|c|c|c|c|}
\hline \multicolumn{7}{|c|}{$\begin{array}{l}\text { The regression equation is } \\
\mathrm{EFF}=0.267+0.129 \text { TOTAVG }\end{array}$} \\
\hline Predictor & Coef & SE Coef & $\mathrm{T}$ & \multicolumn{2}{|r|}{$\mathrm{P}$} & \\
\hline Constant & 0.2675 & 0.1049 & 2.55 & \multicolumn{3}{|c|}{0.038} \\
\hline TOTAVG & 0.12945 & 0.02852 & 4.54 & \multirow{2}{*}{\multicolumn{2}{|c|}{0.003}} & \\
\hline $\mathrm{S}=0.02825 \quad \mathrm{R}$ & $\mathrm{q}=74.6 \%$ & $(\operatorname{adj})=71.0 \%$ & & & & \\
\hline \multicolumn{7}{|c|}{ Analysis of Variance } \\
\hline Source & DV & SS & MS & $\mathrm{F}$ & & $\mathrm{P}$ \\
\hline Regression & 1 & 0.016440 & 0.016440 & 20.59 & & 0.003 \\
\hline Residual Error & 7 & 0.005588 & 0.000798 & & & \\
\hline Total & 8 & 0.022028 & & & & \\
\hline
\end{tabular}

Figure 2. Overall Construct with Technical Efficiency

\begin{tabular}{|c|c|c|c|c|c|c|}
\hline \multicolumn{2}{|c|}{$\mathrm{EFF}=0.127+0.0319 \mathrm{SSP}+0.0157 \mathrm{SCR}+0.0486 \mathrm{INT}+0.0344 \mathrm{LGTT}+0.0408 \mathrm{DP}$} & & & & & \\
\hline Predictor & Coef & SE Coef & $\mathrm{T}$ & & $\mathrm{P}$ & \\
\hline Constant & 0.12701 & 0.05010 & 2.54 & & 0.019 & \\
\hline SSP & 0.03193 & 0.01337 & 2.39 & & 0.026 & \\
\hline SCR & 0.01570 & 0.1917 & 0.32 & & 0.422 & \\
\hline INT & 0.04862 & 0.01374 & 3.54 & & 0.002 & \\
\hline LGIT & 0.03443 & 0.01492 & 2.31 & & 0.031 & \\
\hline DP & 0.04077 & 0.01659 & 2.46 & & 0.022 & \\
\hline $\mathrm{S}=0.04249 \quad \mathrm{R}$ & $q=89.9 \%$ & $\mathrm{R}-\mathrm{Sq}(\mathrm{adj})=87.6 \%$ & & & & \\
\hline \multicolumn{7}{|c|}{ Analysis of Variance } \\
\hline Source & DV & SS & MS & $\mathrm{F}$ & & $\mathrm{P}$ \\
\hline Regression & 5 & 0.352352 & 0.070470 & 39.04 & & 0.000 \\
\hline Residual Error & 22 & 0.039716 & 0.001805 & & & \\
\hline Total & 27 & 0.392068 & & & & \\
\hline
\end{tabular}

Figure 3. SCM Practices with Technical Efficiency 


\section{Appendix A. Instruments for Supply chain management practices}

With regard to the following items, please indicate the degree that your present firm practices (on 5 point Likert scale, 1--- least practice, 5 --- most practice)

\section{Strategic supplier partnership (SSP)}

A1. We select and rely on a small number of high qualified suppliers

A2. We expect our relationship with key suppliers to last a long-time

A3. We regularly solve our problems jointly with our suppliers

A4. We consider our suppliers as an extension of our company

A5. We share sensitive information with our suppliers

A6. We include our key suppliers in our planning and goal-setting activities

\section{Strategic customer relationship (SCR)}

B1. We anticipate and respond to customers' evolving needs and wants

B2. We frequently measure and evaluate customer satisfaction

B3. We emphasize the evaluation of formal and informal customer complaints

B4. Customer focus is reflected in our business planning

B5. We frequently interact with customers to set our competitive priorities

B6. Our customers provide us with changes in purchase order information

B7. Our customers provide us with their inventory level information

B8. Our customers provide us with their future demand forecasting information

B9. Our customers provide us with their production planning information

B10. We provide our customer with our production capacity information

B11. We provide our customers with order status and delivery schedule information

\section{Information technology (IT)}

C1. There is direct computer-to-computer links with key suppliers

C2. Intra-organizational coordination is achieved using electronic links

C3. We have electronic mailing capabilities with our key suppliers

C4. We use electronic transfer of purchase orders invoices and / or funds

C5. Our coordination with suppliers and buyers is achieved using electronic links

Logistics integration (LIT)

D1. Interorganizational logistic activities are closely coordinated

D2. Our logistics integration is characterized by excellent distribution, transportation or warehousing facilities

D3. The inbound and outbound distribution of goods with our suppliers is well integrated

D4. Information and materials flow smoothly between our supplier firms and us

Delivery practices (DP)

E1.We deliver products to our major customer on a just-in-time basis

E2.We consolidate orders by customers, sources, carriers, etc.

E3.We have a single point of contact for all order inquiries

E4.We have real time visibilities of order tracking 